\title{
S A VICTIM ALSO AN ATTACKER? RESEARCH OF CYBERBULLYING AT CZECH PUPILS AND STUDENTS IN THE WHOLE CZECH REPUBLIC II
}

\section{Miroslav CHRÁSKA - Kamil KOPECKÝ - Veronika KREJČÍ - René SZOTKOWSKI}

\begin{abstract}
The article presents other results of research realized in 2011 as a part of a project E-Bezpečí - danger of electronic communication for pupils and teachers (MŠMT 0024/PRV/PK/2010). It answers questions connected with relationship between victim and attacker of cyberbullying.
\end{abstract}

Key words: Cyberbullying, Research, Czech republic, Student, Pupil.

\section{OBĚŤ ÚTOČNÍKEM? VÝZKUM KYBERŠIKANY U DĚTÍ ZÁKLADNÍCH A STŘEDNÍCH ŠKOL V CELÉ ČESKÉ REPUBLICE II}

Resumé: Př́spěvek prezentuje další dílčí závěry výzkumu realizovaného v roce 2011 v rámci projektu E-Bezpečí - nebezpečí elektronické komunikace pro žáky i učitele (MŠMT - 0024/PRV/PK/2010). Uzavírá tak odpověd’ na otázku, zda dítě, které bylo kyberšikanováno, ubližuje „na oplátku“ dalším dětem.

Kličcová slova: Kyberšikana, výzkum, Česká republika, student, žák.

\section{1 Úvod}

Prudký rozvoj informačních a komunikačních technologií $\mathrm{v}$ posledních letech nabízí nejen obrovské možnosti a podstatné usnadnění života, ale přináší též četná rizika, jako je např́klad kyberšikana (kybernetická šikana, cyberbullying) - nebezpečný komunikační jev realizovaný prostřednictvím informačních a komunikačních technologií (ICT), tedy Internetu a mobilních telefonů.

V roce 2010 se v rámci projektu E-Bezpečí nebezpečí elektronické komunikace pro žáky i učitele (MŠMT - 0024/PRV/PK/2010) uskutečnil výzkum, jehož hlavním cílem bylo zjistit, jaké mají žáci našich základních a stř̌edních škol zkušenosti s kyberšikanou. Kromě a deskripce současného stavu jsme chtěli výzkumem ověřit, které hlavní faktory vznik kyberšikany ovlivňují a jak na projevy kyberšikany žáci reagují. Jedním $\mathrm{z}$ dílčích problémů řešených výzkumem bylo hledání odpovědi na otázku, zda a jak se změní chování a jednání žáků, pokud se stali obět’mi kyberšikany.

Příspěvek navazuje na „Obět’ útočníkem? Výzkum kyberšikany u dètí základnich a střednich škol v celé České republice - 1. část" a zjištuje existenci vztahu mezi četnostmi obětí následujících typů kyberšikany: uráženi, zesměšňování, ponižování nebo ztrapňování po- mocí audio nahrávky; vyhrožováni prostřednictvím internetu nebo mobilního telefonu; vydírání pomocí internetu nebo mobilního telefonu; neoprávněné vniknutí do elektronického účtu; zneužití elektronického účtu; obtěžováni opakovaným prozváněním nebo posiláním velkého počtu zpráv - a četnostmi útoků takto napadených žáků vůči jiným osobám.

\section{Formulace a verifikace výzkumných hypotéz}

Ve výzkumu jsme formulovali základní hypotézu: Žáci základních a střednich škol, kteři se stali obětmi kyberšikany, častěji než ostatni žáci šikanuji tímto zpưsobem jiné osoby.

Tu jsme pak ověrovali prostřednictvím devíti dílčích hypotéz $\left(\mathrm{H}_{1}-\mathrm{H}_{9}\right)$, vyjadřujících vztah mezi četnostmi obětí určitého typu kyberšikany a četnostmi útoků takto napadených žáků vůči jiným osobám.

Vzhledem $\mathrm{k}$ tomu, že príspěvek navazuje na „Obět' útočnikem? Výzkum kyberšikany u děti základnich a středních škol $v$ celé České republice - 1. část", uvedeme verifikaci hypotéz $\mathrm{H}_{4}-\mathrm{H}_{9}$.

\section{FORMULACE A VERIFIKACE $\mathrm{H}_{4}$}

Žáci, kteři byli uráženi, zesměšňováni, ponižováni nebo ztrapňováni pomocí audio nahrávky, se tohoto typu útoku vi̊č jiným osobám dopouštěji častěji než ostatní žáci. 
Verifikace této hypotézy vycházela z odpovědí respondentů na otázky č. 10 a 25:

\section{Otázka č. 10}

Siŕril někdo pomocí služeb internetu nebo mobilniho telefonu zvukovou nahrávku, která tě měla ponižit, zesměšnit nebo jinak ztrapnit? ano $x$ ne

\section{Otázka č. 25}

Šiřil jsi pomocí služeb internetu nebo mobilního telefonu zvukovou nahrávku, která méla někoho ponižit, zesměšnit nebo jinak ztrapnit?

ano $x$ ne

Výsledky ověřování $\mathrm{H}_{4}$ jsou uvedeny $\mathrm{v}$ tab. 1 . Respondenti, proti kterým byl veden útok prostřednictvím zvukové nahrávky (urážky, zesměšňování, ponižování, ztrapňování), realizují velmi často stejný typ útoku vůči jiným osobám.

Ze 477 napadených žáků jich 115 , tj. asi $24 \%$, uskutečnilo stejný typ útoku proti jinému člověku. Přitom žáků, kteří se s útokem nesetkali a sami někomu ublížili, jsou jen asi $2 \%$.

Tabulka 1: Výsledky statistického ověřování hypotéz $\mathrm{H}_{4}-\mathrm{H}_{5}$

\begin{tabular}{|l|l|l|}
\hline Hypotéza & $H_{4}$ & $H_{5}$ \\
\hline Typ elektronického útoku & $\begin{array}{c}\text { urážky } \\
\text {,audio“ }\end{array}$ & $\begin{array}{c}\text { vyhrožo } \\
\text { vání }\end{array}$ \\
\hline $\begin{array}{l}\text { Celková četnost } \\
\text { respondentů }\end{array}$ & 10986 & 11118 \\
\hline $\begin{array}{l}\text { Četnost respondento̊, } \\
\text { kteř́ byli tímto způsobem } \\
\text { napadeni }\end{array}$ & 477 & 1832 \\
\hline $\begin{array}{l}\text { Četnost respondentů, } \\
\text { kteří nebyli tímto } \\
\text { způsobem napadeni }\end{array}$ & 10986 & 9286 \\
\hline $\begin{array}{l}\text { Pozorovaná četnost } \\
\text { odpovédi ,ano x ano“ }\end{array}$ & 115 & 336 \\
\hline $\begin{array}{l}\text { Očekávaná četnost } \\
\text { odpovědi ,ano x ano“ }\end{array}$ & 13,1 & 110,9 \\
\hline $\begin{array}{l}\text { Hodnota testového } \\
\text { kritéria chí-kvadrát } \chi^{2}\end{array}$ & 851,0 & 582,332 \\
\hline Fí-koeficient $r_{\Phi}$ & 0,278 & 0,229 \\
\hline $\begin{array}{l}\text { Signifikace } p \quad p \leq 0,00 \\
p\end{array}$ & $p \leq 0,00$ \\
\hline
\end{tabular}

\section{FORMULACE A VERIFIKACE $\mathrm{H}_{5}$}

Žáci, kterým bylo vyhrožováno prostřednictvím internetu nebo mobilniho telefonu, se dopouštěji častěji tohoto typu útoku vưči jiným osobám než ostatní žáci.

Data pro verifikaci této hypotézy jsme získali z odpovědí dotázaných na otázku č. 12 a 27:

Otázka č. 12

Vyhrožoval ti někdo nebo tě zastrašoval pomoci služeb internetu nebo mobilního telefonu?

ano $x$ ne

\section{Otázka č. 27}

Vyhrožoval jsi někomu nebo jsi ho zastrašoval pomocí služeb internetu nebo mobilního telefonu?

ano $x$ ne

Respondenti, kterým bylo prostřednictvím služeb internetu nebo mobilního telefonu vyhrožováno, velmi často uvádějí, že také sami vyhrožují tímto způsobem jiným osobám (srov. tab. 1).

Z 1832 napadených žáků jich 336, tj. asi $18 \%$, prriznalo, že stejný útok realizovalo na jiných osobách. U žáků, kteří se s útokem nesetkali, činí podíl útočníků pouze asi $4 \%$ dotázaných.

\section{FORMULACE A VERIFIKACE $\mathrm{H}_{6}$}

Žáci, kteři byli vydíráni pomoci internetu nebo mobilního telefonu, se častěji dopouštějí tohoto typu útoku vi̊či jiným osobám než ostatni žáci.

Data jsme získali z odpovědí na otázky číslo 14 a 29:

Otázka č. 14

Vydíral tě někdo pomocí služeb internetu nebo mobilního telefonu?

ano $x$ ne

Otázka č. 29

Vydiral jsi někoho pomocí služeb internetu nebo mobilního telefonu?

ano $x$ ne 
Tabulka 2: Výsledky statistického ověřování hypotéz $\mathbf{H}_{6}-\mathrm{H}_{7}$

\begin{tabular}{|l|l|l|}
\hline Hypotéza & $H_{6}$ & $H_{7}$ \\
\hline $\begin{array}{l}\text { Typ elektronického } \\
\text { útoku }\end{array}$ & vydírání & $\begin{array}{l}\text { vniknutí } \\
\text { do el. účtu }\end{array}$ \\
\hline $\begin{array}{l}\text { Celková četnost } \\
\text { respondentů }\end{array}$ & 11085 & 11100 \\
\hline $\begin{array}{l}\text { Četnost respondentů, } \\
\text { kteří byli tímto } \\
\text { způsobem napadeni }\end{array}$ & 692 & 3684 \\
\hline $\begin{array}{l}\text { Četnost respondentů, } \\
\text { kteř́ nebyli tímto } \\
\text { způsobem napadeni }\end{array}$ & 10393 & 7416 \\
\hline $\begin{array}{l}\text { Pozorovaná četnost } \\
\text { odpovědi ,ano x } \\
\text { ano“ }\end{array}$ & 133 & 1561 \\
\hline $\begin{array}{l}\text { Očekávaná četnost } \\
\text { odpovědi } \\
\text {,anox ano“ }\end{array}$ & 17,5 & 996,3 \\
\hline $\begin{array}{l}\text { Hodnota testového } \\
\text { kritéria } \\
\text { chí-kvadrát } \chi^{2}\end{array}$ & 831,607 & 656,547 \\
\hline Fí-koeficient $r_{\Phi}$ & 0,274 & 0,243 \\
\hline $\begin{array}{l}\text { Signifikace } p \\
p\end{array}$ & $p \leq 0,000$ & $p \leq 0,0001$ \\
\hline
\end{tabular}

Z výsledků ověřování šesté hypotézy (tab. 2) jsme zjistili, že respondenti, jež byli vydíráni prostřednictvím služeb mobilního telefonu nebo internetu, vydírají pomocí těchto prostředků jiné osoby - z 692 vydíraných žáků, se jich 133, tj. asi $13 \%$, stalo útočníky a vydíralo druhé. U žáků, kteří sami vydíráni nebyli, tvoří tento podíl pouze asi $1 \%$ útočníků.

\section{FORMULACE A VERIFIKACE $\mathrm{H}_{7}$}

Žáci, kterým někdo vnikl do elektronického účtu, se častěji než ostatni žáci dopouštěji tohoto typu útoku vưči jiným osobám.

Zdrojem dat pro verifikaci hypotézy nám byly odpovědi na otázku číslo 16 a 31:
Otázka č. 16

Dostal se nékdo bez tvého svolení do tvého elektronického účtu (např. do emailového účtu, účtu k chatu, sociálni siti apod.)?

ano $x$ ne

Otázka č. 31

Dostal ses někdy bez svolení majitele do jeho elektronického účtu (napřr. do emailového účtu, účtu $k$ chatu, sociální síti apod.)?

ano $x$ ne

Z výsledků (tab. 2) vyplývá, že respondenti, kterým se někdo (bez jejich svolení) dostal do elektronického účtu, mnohdy kopírují chování útočníka a bez svolení vnikají do účtů jiných osob.

Tento druh útoku byl mezi nežádoucími druhy komunikace uváděn velmi často (setkalo se s ním přibližně $27 \%$ všech dotázaných).

Z celkového počtu 3684 napadených žáků $1561 \mathrm{z}$ nich, tj. asi $42 \%$, uvádí, že realizovali tento druh útoku na jiných osobách. Ve skupině žáků, kteří se s útokem nese-tkali, je podíl útočníků asi $19 \%$.

\section{FORMULACE A VERIFIKACE $\mathrm{H}_{8}$}

Žáci, jejichž účet byl někým zneužit, častěji než ostatní žáci zneuživají účet jiných osob.

Data k ověření osmé hypotézy jsme získali na základě odpovědí žáků na otázky číslo 17 a 32:

Otázka č. 17

Zneužil někdo tvioj účet $k$ tomu, aby tě dostal do problémů?

ano $x$ ne

Otázka č. 32

Zneužil jsi cizí účet $k$ tomu, abys dostal jeho majitele do problémů?

ano $x$ ne

Tabulka 3: Výsledky statistického ověřování hypotéz $\mathrm{H}_{8}-\mathrm{H}_{9}$

\begin{tabular}{|l|l|l|}
\hline Hypotéza & $H_{8}$ & $H_{9}$ \\
\hline $\begin{array}{l}\text { Typ elektronického } \\
\text { útoku }\end{array}$ & $\begin{array}{l}\text { zneužití } \\
\text { el. účtu }\end{array}$ & obtěžování \\
\hline $\begin{array}{l}\text { Celková četnost } \\
\text { respondentů }\end{array}$ & 1714 & 11095 \\
\hline
\end{tabular}




\begin{tabular}{|l|l|l|}
\hline $\begin{array}{l}\text { Četnost respondentů, } \\
\text { kteř́ byli tímto } \\
\text { způsobem napadeni }\end{array}$ & 429 & 2858 \\
\hline $\begin{array}{l}\text { Četnost respondentů, } \\
\text { kteří nebyli tímto } \\
\text { způsobem napadeni }\end{array}$ & 1285 & 8237 \\
\hline $\begin{array}{l}\text { Pozorovaná četnost } \\
\text { odpovědi „ano x } \\
\text { ano“ }\end{array}$ & 115 & 420 \\
\hline $\begin{array}{l}\text { Očekávaná četnost } \\
\text { odpovědi } \\
\text {,ano x ano }\end{array}$ & 51,1 & 191,1 \\
\hline $\begin{array}{l}\text { Hodnota testového } \\
\text { kritéria } \\
\text { chí-kvadrát } \chi^{2}\end{array}$ & 121,232 & 395,587 \\
\hline Fí-koeficient $r_{\Phi}$ & 0,266 & 0,189 \\
\hline Signifikace $p$ & $p \leq 0,000$ & $p \leq 0,0001$ \\
\hline
\end{tabular}

Z výsledků jsme se opět dozvěděli, že respondenti, kterým bylo ubližováno, sami druhým ubližují, viz tab. 3.

Ze 429 napadených žáků jich 115 , tj. asi $27 \%$, uvedlo, že stejným způsobem atakovalo jiného člověka. Ve skupině žáků, jež se s útokem nesetkali, zaútočilo proti jiným pouze asi $7 \%$ dotázaných.

\section{FORMULACE A VERIFIKACE $\mathrm{H}_{9}$}

Žáci, kteři byli obtěžováni opakovaným prozváněním nebo posiláním velkého počtu zpráv, se častěji než ostatni žáci dopouštěji tohoto typu útoku vioči jiným osobám.

Data důležitá pro verifikaci poslední hypotézy jsme získali opět prostřednictvím některých položek $\mathrm{v}$ dotazníku, konkrétně se jednalo o otázky číslo 18 a 35:

\section{Otázka č. 18}

Obtěžoval tě někdy někdo neustálým prozváněním nebo opakovaným posíláním velkého množství zpráv, které ti velmi vadilo a znepríjemnilo ti život?

ano $x$ ne

\section{Otázka č. 35}

Obtěžoval jsi někoho neustálým prozváněním nebo opakovaným posiláním velkého množstvi zpráv, abys mu znepř́jemnil život?

ano $x$ ne
$\mathrm{Z}$ výsledků uvedených $\mathrm{v}$ tab. 3 je patrné, že respondenti, kteří byli obtěžováni opakovaným prozváněním nebo posíláním velkého počtu zpráv, velmi často obtěžují stejným způsobem jiné osoby.

Z celkového počtu 2858 napadených žáků jich 420 , tj. asi $15 \%$, uskutečnilo stejný typ útok vůči jiným lidem. Ve skupině žákù, kteří se nestali obětí útočníka, napadala jiné jen asi $4 \%$ $\mathrm{z}$ nich.

\section{Závěr}

U všech sledovaných typů elektronických útoků bylo prokázáno, že se útočníci rekrutují nejčastěji z řad obětí kyberšikany. Na základě statistické analýzy výsledků byly na velmi vysoké hladině významnosti $\mathrm{p} \leq 0,0001$ prijaty všechny formulované dílčí hypotézy. A vzhledem $\mathrm{k}$ jednoznačným výsledkům verifikace dílčích hypotéz je možné přijmout i hypotézu základní. Výzkum tedy prokázal, že žáci základnich a střednich škol, kteř̀ se stali obětmi kyberšikany, častěji než ostatni žáci, šikanují tímto způsobem jiné osoby.

Výsledky a z nich plynoucí vysoce signifikantní závěry byly získány především díky velkému rozsahu šetření, jež bylo dáno výběrem cca 12000 respondentů z celé České republiky.

Kompletní výzkumná zpráva je $\mathrm{k}$ dispozici na stránkách Centra prevence rizikové virtuální komunikace (http://prvok.upol.cz) - viz [1].

\section{Literatura}

[1] KOPECKÝ, K.; KREJČÍ, V. Nebezpeči elektronické komunikace 2. Zpráva z výzkumného šetření. [online]. 2010-2011. URL: <http://prvok.upol.cz/index.php/ke-staeni/doc_do wnload/13-nebezpei-elektronicke-komunikace-2centrum-prvok-2011>.

[2] BELSEY, B. Always on, always aware. [online]. 2004. URL: <http://www.cyberbullying. ca/pdf/Cyberbullying_Information.pdf $>$.

[3] CHRÁSKA, M. Metody pedagogického výzkumu: základy kvantitativního výzkumu. 1. vyd. Praha : GRADA, 2007. 265 s. ISBN 97880-247-1369-4.

[4] KOLÁŘ, M. Nová cesta $k$ léčbě šikany. 1. vyd. Praha : Portál, 2011. 332 s. ISBN 978-807367-871-5.

[5] KOWALSKI, R.; LIMBER, S.; AGATSTON, P. Cyber Bullying: Bullying in the Digital Age. 1. vyd. Malden, MA. : Blackwell Publishers, 2007. 224 s. ISBN 978-1405159920. 
[6] MŠMT. Metodický pokyn ministra školství, mládeže a tělovýchovy $k$ prevenci a řšseni šikanováni mezi žáky škol a školských zařizení, C.j. 24 246/2008-6. [online]. [cit. 2012-01-4]. URL: <http://www.msmt.cz/pro-novinare/metodi cky-pokyn-k-prevenci-a-reseni-sikanovani-mezizaky>.

[7] SMITH, P. K.; SLONJE, R. Cyberbullying: the nature and extent of a new kind of bul-lying, in and out of school. In JIMERSON, S. R. The International Handbook of School Bullying. 1. vyd. New York : Routledge, 2010. 624 s. ISBN 978-0805863932.

[8] ŠMAHEL, D. Psychologie a internet: déti dospélými, dospéli détmi. 1. vyd. Praha : Triton, 2003. 158 s. ISBN 80-7254-360-1.

prof. PhDr. Miroslav Chráska, CSc.

Ústav pedagogických věd

Fakulta humanitních studií UTB

Mostní 5139

76001 , Zlín, ČR

Tel: +420 576037430

E-mail: chraska@fhs.utb.cz

Www pracovišstě: http://web.fhs.utb.cz/
Mgr. Kamil Kopecký, Ph.D.

Katedra českého jazyka a literatury

Pedagogická fakulta UP

Žižkovo nám. č. 5

771 40, Olomouc, ČR

Tel: +420 585635601

E-mail: kamil.kopecky@upol.cz

Www pracoviště: http://kcjl.upol.cz/

Mgr. Veronika Krejčí

Centrum prevence rizikové virtuální komunikace

Pedagogická fakulta UP

Žižkovo nám. č. 5

771 40, Olomouc, ČR

Tel: +420 585635614

E-mail: veronika.krejci@upol.cz

Www pracoviště: http://www.prvok.upol.cz

PhDr. René Szotkowski, Ph.D.

Ústav pedagogiky a sociálních studií

Pedagogická fakulta UP

Žižkovo nám. č. 5

771 40, Olomouc, ČR

Tel: +420 585635178

E-mail: rene.szotkowski@upol.cz

Www pracoviště: www.upss.cz 